\title{
Trichothecene Mycotoxins Associated with Potato Dry Rot Caused by Fusarium graminearum
}

\author{
Javier A. Delgado, Paul B. Schwarz, James Gillespie, Viviana V. Rivera-Varas, and Gary A. Secor
}

First, fourth, and fifth authors: Department of Plant Pathology, and second and third authors: Department of Plant Sciences, North Dakota State University, Fargo 58105.

Accepted for publication 3 November 2009.

\begin{abstract}
Delgado, J. A., Schwarz, P. B., Gillespie, J., Rivera-Varas, V. V., and Secor, G. A. 2010. Trichothecene mycotoxins associated with potato dry rot caused by Fusarium graminearum. Phytopathology 100:290-296.

Fusarium graminearum, a known producer of trichothecene mycotoxins in cereal hosts, has been recently documented as a cause of dry rot of potato tubers in the United States. Due to the uncertainty of trichothecene production in these tubers, a study was conducted to determine the accumulation and diffusion of trichothecenes in potato tubers affected with dry rot caused by $F$. graminearum. Potato tubers of cv. Russet Burbank were inoculated with $14 \mathrm{~F}$. graminearum isolates from potato, sugar beet, and wheat and incubated at 10 to $12^{\circ} \mathrm{C}$ for 5 weeks to determine accumulation of trichothecenes in potato tubers during storage. Twelve of the isolates were classified as deoxynivalenol

Trichothecenes were detected only in rotted tissue. DON was detected in all $F$. graminearum DON genotype isolates up to $39.68 \mu \mathrm{g} / \mathrm{ml}$ in rotted potato tissue. Similarly, both NIV genotype isolates accumulated NIV in rotted potato tissue up to $18.28 \mu \mathrm{g} / \mathrm{ml}$. Interestingly, isolates classified as genotype DON accumulated both DON and NIV in the dry rot lesion. Potato tubers were then inoculated with two isolates of $F$. graminearum chemotype DON and incubated up to 7 weeks at 10 to $12^{\circ} \mathrm{C}$ and assayed for DON diffusion. F. graminearum was recovered from $>53 \%$ of the isolations from inoculated tubers at $3 \mathrm{~cm}$ distal to the rotted tissue after 7 weeks of incubation but DON was not detected in the surrounding tissue. Based in this data, the accumulation of trichothecenes in the asymptomatic tissue surrounding dry rot lesions caused by $F$. graminearum is minimal in cv. Russet Burbank potato tubers stored for 7 weeks at customary processing storage temperatures.
\end{abstract} (DON) genotype and two isolates were as nivalenol (NIV) genotype.
Fusarium dry rot (FDR) is one of the most important and common post-harvest diseases of stored potato tubers worldwide (33). Fusarium sambucinum Fuckel (teleomorph Gibberella pulicaris (Fr.) Sacc.) is the most common FDR pathogen in North America and Europe, although other Fusarium spp. have been also reported $(1,29,33)$. The natural occurrence of FDR caused by F. graminearum Schwabe (teleomorph G. zeae (Schwein.) Petch) was reported in 2005 in naturally infected, commercially stored potato tubers in North Dakota and Minnesota (2). Subsequently, a survey of stored potato tubers affected by FDR from commercial storage facilities conducted during 2004-05 determined that $58 \%$ of the Fusarium spp. isolated was F. sambucinum and $42 \%$ was $F$. graminearum (18). This suggests an expanded host range of $F$. graminearum and has implications in the epidemiology, management, and toxicology of this fungal pathogen in both cereal and potato crops, since potato has been traditionally used in rotation with wheat, barley, and corn. Outbreaks of Fusarium head blight (FHB) have occurred on significant acreage of wheat and barley within the region since 1993, and these have likely increased the amount of $F$. graminearum inoculum.

Type B trichothecenes such as deoxynivalenol (DON), nivalenol (NIV), 3-acetyldeoxynivalenol (3ADON) and 15-acetyldeoxynivalenol (15ADON) produced by $F$. graminearum have been detected in wheat and barley samples from FHB-impacted regions in the upper Midwestern United States and in maize

Corresponding author: G. A. Secor; E-mail address: gary.secor@ndsu.edu

doi:10.1094/PHYTO-100-3-0290

(c) 2010 The American Phytopathological Society samples affected by maize ear rot in Europe $(11,25,26)$. Trichothecenes have been found to be a virulence factor in the pathogenesis of Fusarium spp. For example, DON is a virulence factor in the pathogenicity of $F$. graminearum in wheat heads (i.e., isolates of $F$. graminearum that produce lesser amounts of DON are less virulent on wheat heads and vice versa). In contrast, 15diacetoxyscirpenol (DAS) is not a virulence factor of $F$. sambucinum in potato tubers $(13,30)$. Recently, isolates of $F$. graminearum collected from wheat, sugar beet, and potato were shown to be equally aggressive in potato tubers (18) and genetically similar, appearing to be part of a single large population in the north-central United States (5). Only type A trichothecenes, such as DAS, have been detected in potato tubers affected with FDR caused by $F$. sambucinum $(16,17,22)$. The finding of $F$. graminearum as an FDR pathogen raises the possibility of accumulation of type B trichothecenes in infected potato tubers and their persistence in fresh and processed potato products. Trichothecenes have been proven to be heat stable and resist degradation by many food-processing treatments $(4,24,36)$. The consumption of these toxins may represent a new concern for the potato industry, especially if these trichothecenes were to be found in asymptomatic tissue surrounding FDR lesions. Removal of dry rot lesions from affected potato tubers is a common practice of consumers and processors but the effect of this practice on trichothecene removal is unknown. The study of the production and accumulation of type B trichothecenes in potato tubers affected by $F$. graminearum has significant implications in the assessment of the toxicological potential of potato tubers naturally affected by FDR. The present study was conducted to determine the accumulation of type B trichothecenes in rotted tissue of potato tubers infected by $F$. graminearum, and the diffusion of the trichothecene DON into the adjacent asymptomatic tissue when stored at processing storage temperatures of 10 to $12^{\circ} \mathrm{C}$. 


\section{MATERIALS AND METHODS}

Source of $\boldsymbol{F}$. graminearum isolates. Fourteen isolates of $F$. graminearum originally isolated from diseased potato tubers, sugar beet roots, and wheat heads were used in this study (Table 1). The isolates were selected because of their ability to cause FDR in stored potato tubers (18). For all experiments, the isolates were grown for 7 days at room temperature under a 24-h fluorescent light regimen (40-W bulbs) on half-strength potato dextrose agar (PDA) (potato dextrose broth at $12 \mathrm{~g} /$ liter and agar at $15 \mathrm{~g} /$ liter).

Genotype and chemotype determination of isolates. Genotype determination was conducted using $F$. graminearum DNA extracted using the cetyltrimethylammonium bromide method described by Nicholson et al. (28). The DON genotype determination was conducted by polymerase chain reaction (PCR) using the following primer sets Tri7DON, MinusTri7, and Tri13DON. Likewise, the NIV genotype determination was also conducted by PCR using the primer sets Tri7NIV and Tri13NIV according to Chandler et al. (7). The amplified PCR fragment sizes were 381 to $445 \mathrm{bp}$ for Tri7DON assay, $483 \mathrm{bp}$ for MinusTri7 assay, $282 \mathrm{bp}$ for Tri13DON assay, $465 \mathrm{bp}$ for Tri7NIV assay, and $312 \mathrm{bp}$ for Tri13NIV assay.

The DON/NIV chemotype determination was performed according to Sugiura et al. (34) and conducted three times with two replications per experiment. Sterile rice was inoculated with a solution of $1 \times 10^{4} \mathrm{~F}$. graminearum macroconidia per milliliter from a 7-day-old PDA culture and grown as previously indicated. The rice culture was incubated in the dark at room temperature for 28 days prior to assay. The rice culture was freeze dried, finely ground in a sterile mortar, and extracted using a solution of acetonitrile:water $(84: 16, \mathrm{vol} / \mathrm{vol})$ for gas chromatographic mass spectrometry (GC-MS) analysis according to Schwarz et al. (32), with modifications. Briefly, a 4-ml aliquot of the extract was applied to an 8-ml C18:alumina solid-phase clean-up column (AFT Extract-Clean Columns; Grace Davison Discovery Sciences, Deerfield. IL). A 2-ml aliquot of eluant was transferred into a 13by-100-mm screw-capped test tube and evaporated to dryness with $\mathrm{N}_{2}$ at $60^{\circ} \mathrm{C}$. The derivatization of the residue was made by adding $100 \mu \mathrm{l}$ of BSTFA:pyridine:TMCI:TMCS (1:1:1:1). The tube was capped, agitated using a vortex mixer for $10 \mathrm{~s}$, and allowed to react for $30 \mathrm{~min}$ at room temperature. Then, a $1 \mathrm{ml}$ of internal standard solution (Mirex, $0.5 \mu \mathrm{g} / \mathrm{ml}$ ) was added and swirled, and $1 \mathrm{ml}$ of $3 \% \mathrm{NaHCO}_{3}$ was added. The tube was agitated twice using a vortex mixer for $10 \mathrm{~s}$ each time and allowed to settle for $15 \mathrm{~min}$, for separation of layers. The top layer $(2,2,4-$ trimethylpentane) was transferred to an autosampler vial to be analyzed by GC-MS in single-ion-monitoring mode. Single-ion monitoring was performed on a quadrapole mass spectrometer (Agilent Technologies 5973 inert; Agilent Technologies Inc., Santa Clara, CA). Chromatographic separations were conducted using a gas chromatographer (Agilent Technologies 6890N; Agilent Technologies Inc.) using a fused-silica capillary column of $30 \mathrm{~m}$ by $250-\mu \mathrm{m}$ (i.d.) with a $0.25-\mu \mathrm{m}$ coating of $35 \%$ diphenyl polysoloxane (Rtx-35MS; Restek, Bellefonte, PA) in splitless mode with helium as carrier gas at a purge flow of $3.0 \mathrm{ml} / \mathrm{min}$. Injections were performed at a volume of $3.0 \mu \mathrm{l}$. The initial temperature of the column oven was $80^{\circ} \mathrm{C}$ held for $1 \mathrm{~min}$. Later, the oven was ramped to $280^{\circ} \mathrm{C}$ at $7.5^{\circ} \mathrm{C} / \mathrm{min}$, and then ramped from 280 to $310^{\circ} \mathrm{C}$ and held for $5 \mathrm{~min}$ at $310^{\circ} \mathrm{C}$. Mass spectrometer conditions were ion source temperature of $230^{\circ} \mathrm{C}$ and quadrapole temperature of $150^{\circ} \mathrm{C}$. The key ion fragments $(\mathrm{m} / \mathrm{z})$ for DON were $235.2,422.3$, and $512.3 \mathrm{~m} / \mathrm{z}$, with a retention time of $22.59 \mathrm{~min}$; for NIV, $289.2,379.2$, and $482.3 \mathrm{~m} / \mathrm{z}$ with a retention time of $23.81 \mathrm{~min}$; for 3ADON, 163.1, 392.2, and $467.3 \mathrm{~m} / \mathrm{z}$, with a retention time of $24.59 \mathrm{~min}$; and for 15-ADON, 193.2, 392.2, and $467.3 \mathrm{~m} / \mathrm{z}$, with a retention time of $24.76 \mathrm{~min}$. For Mirex, the key ion fragments were 236.9, 271.9, and $331.9 \mathrm{~m} / \mathrm{z}$ with a retention time of $27.87 \mathrm{~min}$. Limits of quantification were as follows: DON, 0.04 to $120 \mu \mathrm{g} / \mathrm{ml}$; 3ADON and 15ADON, 0.04 to $12 \mu \mathrm{g} / \mathrm{ml}$, and NIV, 0.2 to $30 \mu \mathrm{g} / \mathrm{ml}$.

A known field corn sample naturally contaminated with high levels of DON was used as a control for the performance of the trichothecene extraction and analysis procedure. In addition, one negative rice control and two spiked rice controls were used. The spiked controls were prepared by adding a solution of trichothecenes to freeze-dried clean rice eluant from the 2-ml aliquot stage (described above) with either 10 or $100 \mu$ of standard solution containing DON at $20 \mu \mathrm{g} / \mathrm{ml}$ and 3ADON, 15ADON, and $\mathrm{NIV}$ at $2 \mu \mathrm{g} / \mathrm{ml}$. The standard trichothecenes were purchased from Sigma-Aldrich (St. Louis).

Determination of trichothecenes in potato tubers infected with $\boldsymbol{F}$. graminearum. Potato tubers of cv. Russet Burbank were used in this study because Russet Burbank is the most frequently planted cultivar in North Dakota and Minnesota, with $>50 \%$ of planted acreage (27); the predominate cultivar used for processing; and susceptible to FDR (8). Potato tubers were harvested from a North Dakota State University research field site and stored at $4{ }^{\circ} \mathrm{C}$ for 1 month. Prior to inoculation, disease-free tubers were selected and conditioned to room temperature overnight. The potato tubers were washed free of soil, surface disinfected by immersion in $0.05 \% \mathrm{NaClO}$ for $10 \mathrm{~min}$, rinsed three times with running tap water, and air dried overnight. Tubers were inoculated by aseptically removing a plug of potato tuber tissue $(5 \mathrm{~mm}$ in diameter by $1 \mathrm{~cm}$ in depth) from the stem end with a cork borer. The resulting cavity was inoculated with a mycelial plug $(5 \mathrm{~mm}$ in diameter) from a 7-day-old $F$. graminearum culture grown on half-strength PDA. The inoculated tubers were incubated in plastic boxes ( 24 by 33 by $11 \mathrm{~cm}$ ) previously lined with a sterile moist paper towel and a plastic grid at the bottom. The boxes were closed with a lid and incubated in a growth chamber for 5 weeks at 10 to $12^{\circ} \mathrm{C}$ in the dark. The experimental design was a complete random design with five replications of four tubers each. Each box corresponded to a single replication. Two such trials were performed. The severity of the FDR lesion was evaluated by cutting the inoculated tubers longitudinally and measuring the width and depth of the lesion with a ruler. The volume of each lesion was calculated according to Peters et al. (29). Subsequently, the rotted tissue was excised from each tuber and placed in a plastic bag. Additionally, a cube $\left(1 \mathrm{~cm}^{3}\right)$ of asymptomatic tissue immediately adjacent to the lesion was excised from each tuber, and placed in a plastic bag. Both bags were stored at $-20^{\circ} \mathrm{C}$ until trichothecene extraction. The rotted tissue of each tuber, or the adjacent asymptomatic tissue, were separately combined from individual tubers (bags) to fulfill the minimum amount of tissue necessary per replication for the trichothecene extraction. The

TABLE 1. Identity, host, and origin of Fusarium graminearum isolates

\begin{tabular}{ll}
\hline Isolate & Host and origin \\
\hline W09 & Wheat, ID $^{\mathrm{x}}$ \\
W10 & Wheat, ID \\
P15 & Potato, MNy \\
P16 & Potato, MN \\
P17 & Potato, MN \\
S19 & Sugar beet, MN \\
S21 & Sugar beet, MNy \\
S22 & Sugar beet, MN \\
S23 & Sugar beet, MD \\
W31 & Wheat, ND \\
W34 & Wheat, ND \\
W36 & Wheat, ND $^{\mathrm{z}}$ \\
W37 & ${\text { Wheat, } \text { ND }^{\mathrm{z}}}_{\text {W38 }}^{\mathrm{y}}$ \\
\hline
\end{tabular}

x Juliet Windes, University of Idaho.

y Rolando Estrada, North Dakota State University.

z Shaukat Ali, North Dakota State University. 
collected samples were freeze dried and ground in a porcelain mortar prior to trichothecene analysis by thin-layer chromatography (TLC) and GC-MS.

The rotted tissue was analyzed by TLC to determine the presence of DON and NIV. The trichothecene extraction was conducted using acetonitrile as described before. After the cleaning step, a 5-ml aliquot of the eluant was transferred into a test tube and dried as described previously. Then, the residue was resuspended in $150 \mu \mathrm{l}$ of acetonitrile:methanol (95:5). The TLC analysis was carried out as previously described by Ichinoe et al. (20) and Samson et al. (31), with modifications. An aliquot of $40 \mu \mathrm{l}$ of stored trichothecene solution was spotted in a normalphase $250-\mu \mathrm{m}$ silica-gel TLC plate. The following solvents were used to separate the compounds: toluene:ethyl acetate:formic acid $(90 \%)$ at 5:4:1 ratio (TEF), toluene:acetone:methanol at 5:3:2 ratio (TAM), and chloroform:acetone:2-propanol at 85:15:20 ratio (CAP). The visualization of the trichothecenes was achieved by spraying $20 \%$ of $\mathrm{AlCl}_{3}$ in $60 \%$ ethanol and heating for $8 \mathrm{~min}$ at $130^{\circ} \mathrm{C}$ in an oven. The trichothecenes were observed under UV light as a blue fluorescent spot. Two standards were spotted in this assay: $30 \mu \mathrm{l}$ of DON at $200 \mu \mathrm{g} / \mathrm{ml}$ in ethyl acetate:methanol (95:5) and $20 \mu \mathrm{l}$ of griseofulvin at $10 \mathrm{mg} / \mathrm{ml}$ in acetonitrile:methanol (8:2). The retardation factors relative to griseofulvin $\left(\mathrm{R}_{\mathrm{fg}}\right)$ for DON and NIV obtained during the TLC analysis were compared with the tabulated $\mathrm{R}_{\mathrm{fg}}$ values reported in Samson et al. (31). Tabulated $\mathrm{R}_{\mathrm{fg}}$ for DON were $0.48,0.87$, and 0.62 in solvent systems TEF, TAM, and CAP, respectively. For NIV, the $\mathrm{R}_{\mathrm{fg}}$ were $0.18,0.66$, and 0.28 in TEF, TAM, and CAP, respectively. GC-MS analysis of the rotted and adjacent asymptomatic potato tissue was also conducted as described previously.

DON diffusion and $F$. graminearum penetration in inoculated potato tubers. This experiment was carried out according to the methods described by Laidou et al. (23), with the following modifications. Potato tubers (cv. Russet Burbank) were conditioned as previously described. Tubers were inoculated with two F. graminearum chemotype DON isolates (P17 and S23) and incubated at 10 to $12^{\circ} \mathrm{C}$ as previously describe for 3,5 , or 7 weeks. The experiment was conducted in a complete random design with three replications of three tubers each. Two such trials were performed. After each incubation time, the tubers were evaluated by cutting them longitudinally through the center of the FDR lesion. The rotted tissue was excised from the potato tubers and frozen until trichothecene analysis. From the adjacent asymptomatic tissue, three tissue samples (sections) were collected at 1,
2, and $3 \mathrm{~cm}$ distal to the FDR lesion margin and designated as A, $\mathrm{B}$, and $\mathrm{C}$, respectively. The sections were $1 \mathrm{~cm}$ in thickness and $1 \mathrm{~cm}^{3}$ in volume, and were collected from each half of the potato tubers with a sterile knife. These three sections were placed in plastic bags and stored at $-20^{\circ} \mathrm{C}$ until trichothecene extraction as previously described. In addition, two small pieces of potato tissue were collected from the lesion margin and from the distal portion of each section, and placed on half-strength PDA for $F$. graminearum growth. These cultures were incubated for 7 days at room temperature as previously described, and the frequency of $F$. graminearum isolation was recorded. The frequency of isolation was calculated for each section as percentage of the number of $F$. graminearum-growing potato pieces over the number of potato pieces placed onto half-strength PDA (i.e., a total of six potato pieces per section per replication).

Statistical analyses. Statistical analyses were conducted using the Statistical Analysis Software (SAS) (version 9.1; SAS Institute, Inc., Cary, NC). The homogeneity of variance between the trials was analyzed using Levene's test of homogeneity (PROC TTEST) to determine if trials could be combined for the data prior to further analysis using lesion volume, toxin concentration, and frequency of $F$. graminearum isolation as dependent variables for FDR severity, trichothecene levels, and F. graminearum recovery from potato tubers, respectively. The data were analyzed by analysis of variance (ANOVA) using the ANOVA procedure (PROC ANOVA). Means were compared using Fisher's protected least significant difference at $\alpha=0.05$.

\section{RESULTS}

Genotype and chemotype determination of $F$. graminearum isolates. With the exception of isolates $\mathrm{P} 15$ and $\mathrm{P} 16$, all $F$. graminearum isolates used in this study were classified as DON genotypes, yielding a Tri13DON DNA fragment of 282 bp and either a Tri7DON DNA fragment of $\approx 400$ bp or a Minus Tri7 DNA fragment of 483 bp (Table 2). Isolates P15 and P16 were classified as the NIV genotype, because both showed a Tri7NIV DNA fragment of $465 \mathrm{bp}$ and a Tril3NIV DNA fragment of 312 bp. Isolates P15 and P16 were not classified in the NIV chemotype because NIV was detected under the limit of quantification in rice culture extracts. Similarly, isolate W10 was not classified as DON chemotype because DON was detected under the limit of quantification. The remaining isolates were classified as DON chemotypes, accumulating DON in levels of 0.09 to $41.18 \mu \mathrm{g} / \mathrm{ml}$ (Table 2).

TABLE 2. Determination of genotypes and chemotypes of 14 Fusarium graminearum isolates used in potato tuber inoculations by polymerase chain reaction (PCR) and gas chromatographic mass spectrometry (GC-MS) analysis of rice cultures ${ }^{\mathrm{w}}$

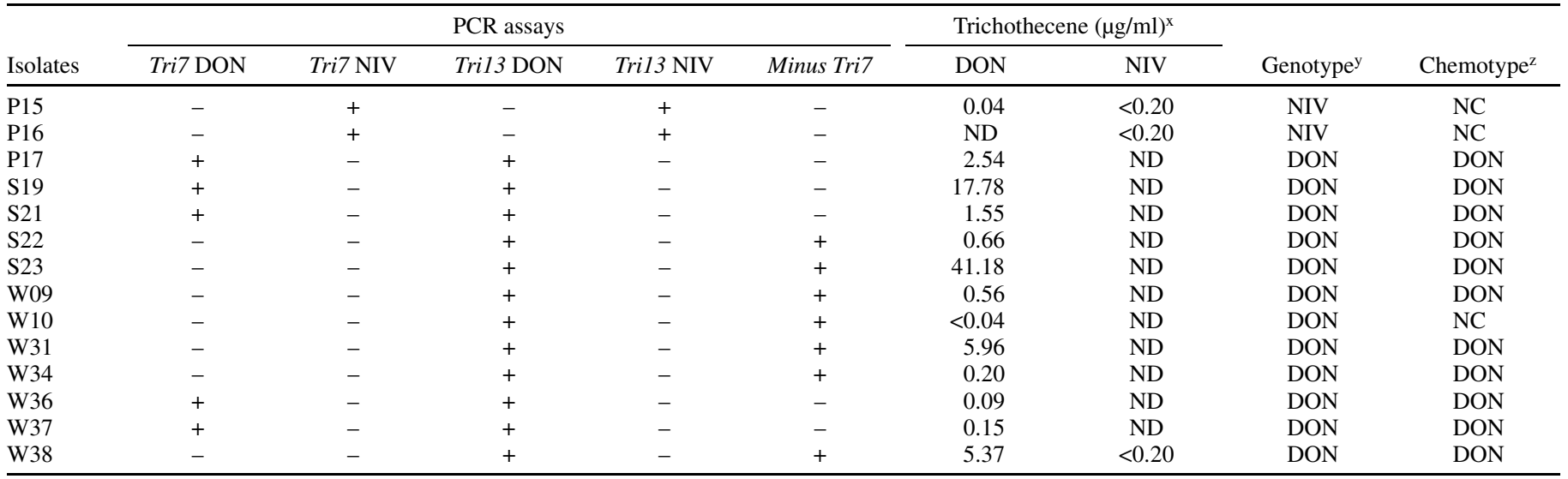

${ }^{\mathrm{w}}$ DON = deoxynivalenol; NIV = nivalenol; < indicates trichothecenes detected under the limit of quantification; NC indicates not-classified chemotype; and ND indicates no detected trichothecene.

$x$ Trichothecene concentration in rice extracts.

${ }^{y}$ DON and NIV genotypes were determined by PCR assays performed according to Chandler et al. (7).

${ }^{z}$ DON and NIV chemotypes were determined by GC-MS analysis of $F$. graminearum isolates grown on rice culture according to Sugiura et al. (34). 
Detection of DON and NIV in rotted tissue of potato tubers by TLC analysis. The TEF solvent system was determined to be the most suitable solvent system for DON and NIV detection in potato tubers based upon the comparison of the calculated $R_{f g}$ values to tabulated $R_{f g}$ values for DON. The reference $R_{f g}$ for DON is 0.48 and for NIV is 0.18 in the TEF solvent system according to Samson et al. (31). DON was detected in rotted potato tissue from the 12 isolates classified under the DON genotype. NIV was detected in 9 of these 12 isolates (Table 3). In addition, only NIV was detected in rotted tissue of potato tubers inoculated with isolates P15 and P16, which were previously classified as NIV genotypes.

Detection and quantification of trichothecenes by GC-MS analysis of rotted and adjacent asymptomatic tissue. The trichothecenes DON, NIV, 3ADON, and 15ADON were detected by GC-MS in potato tubers inoculated with $F$. graminearum (Table 3). Levene's test of homogeneity of variances for trichothecene quantification showed homogeneous variances between trials with $P$ values of $0.07,0.64,0.05$, and 0.75 respectively; therefore, the data from both trials were combined for further analysis. All four trichothecenes were detected in the dry-rotted tissue of potato tubers. In the adjacent asymptomatic tissue, DON was detected in concentrations under the limit of quantification, and NIV, 3ADON, and 15ADON were not detected. The ANOVA showed significant differences between rotted and adjacent asymptomatic tissue in the accumulation of trichothecenes $(P<$ $0.0001)$. Average concentration of total trichothecenes in the rotted tissue was significantly different from the adjacent asymptomatic tissue $(P<0.0001)$. The average concentration for total trichothecenes was $18.92 \mu \mathrm{g} / \mathrm{ml}$ in the rotted tissue, whereas trichothecenes in the adjacent asymptomatic tissue were detected only under the limit of quantification.

The ANOVA of the rotted tissue showed significant differences among isolates $(P<0.0001)$. Similarly, significant differences were detected among DON, NIV, 3ADON, and 15ADON $(P<$ $0.0001)$ and also between trichothecene and isolate interaction $(P<0.0001)$. DON and NIV were accumulated in the rotted tissue of potato tubers by every isolate of $F$. graminearum. DON was accumulated in the rotted tissue of all isolates, with concentrations ranging from below the limit of quantification to
$39.68 \mu \mathrm{g} / \mathrm{ml}$. NIV also accumulated in the rotted tissue of all isolates, with concentrations of 1.40 to $18.28 \mu \mathrm{g} / \mathrm{ml}$. 3ADON was detected in rotted tissue ranging from nondetected to $2.02 \mu \mathrm{g} / \mathrm{ml}$, with a frequency of occurrence of $85.7 \%$ among isolates. The trichothecene $15 \mathrm{ADON}$ was not detected at $>0.75 \mu \mathrm{g} / \mathrm{ml}$ by any isolate included in this present study, ranging from not detected to $0.75 \mu \mathrm{g} / \mathrm{ml}$, with a frequency of occurrence of $71.43 \%$ among isolates. NIV genotype isolates accumulated high amounts of NIV only in rotted tissue of potato tubers, whereas the DON genotype isolates accumulated both DON and NIV in rotted tissue of potato tubers. Seven DON genotype isolates accumulated more NIV than DON (Table 3).

Severity of FDR caused by $\boldsymbol{F}$. graminearum. The two experiments testing the severity of FDR could not be combined because Levene's test of homogeneity of variances indicated that the variances of the trials were not homogenous $(P<0.0001)$. The ANOVA indicated that the isolates differed significantly from each other in the virulence $(P<0.0001$ for trial 1 and $P=0.0007$ for trial 2). All isolates were pathogenic and caused dry rot but isolates W37, S23, W31, and S19 were the most aggressive in this study (Table 3 ).

Trichothecene diffusion and $\boldsymbol{F}$. graminearum penetration in inoculated potato tubers. According to Levene's test, the variances of the recovery of $F$. graminearum and the accumulation of DON in potato tubers were homogeneous between the trials, with a $P$ value of 0.94 and 0.56 , respectively; therefore, the data of both trials were combined for further analysis. The ANOVA of the recovery of $F$. graminearum from potato tubers in the diffusion study showed significant differences among incubation time $(P<0.0001)$ and sections $(P<0.0001)$ as well as a significant interaction between incubation time and sections $(P=0.0002)$. This interaction was expected as a result of the colonization of the tubers that occurred over time by $F$. graminearum. The recovery of $F$. graminearum from the rotted tissue was $60 \%$ after 3 weeks of incubation, which was significantly different from the adjacent asymptomatic tissue 1,2 , and $3 \mathrm{~cm}$ away from the lesion margin (Table 4). A recovery of $25 \%$ was obtained from $1 \mathrm{~cm}$ distal to the lesion margin, which was not significantly different from $2 \mathrm{~cm}$ distal to the lesion but was significantly different from the rotted tissue and the section of

TABLE 3. Disease severity and trichothecene accumulation in the rotted tissue of potato tubers inoculated with Fusarium graminearum isolates ${ }^{t}$

\begin{tabular}{|c|c|c|c|c|c|c|c|c|}
\hline \multirow[b]{2}{*}{ Isolate } & \multicolumn{2}{|c|}{ FDR severity $\left(\mathrm{mm}^{3}\right)^{\mathrm{u}}$} & \multirow[b]{2}{*}{ TLC $^{\mathrm{w}}$} & \multicolumn{4}{|c|}{ Trichothecenes detected by GC-MS $(\mu \mathrm{g} / \mathrm{ml})^{\mathrm{v}}$} & \multirow[b]{2}{*}{ Total $(\mu \mathrm{g} / \mathrm{ml})^{\mathrm{x}}$} \\
\hline & Trial 1 & Trial 2 & & DON & NIV & 3ADON & $15 \mathrm{ADON}$ & \\
\hline P15 & $8.18 \mathrm{~cd}$ & $1.64 \mathrm{e}$ & NIV & $<0.04$ & $8.18 \mathrm{~b}$ & 0.32 ef & $<0.04 \mathrm{~b}$ & $8.55 \mathrm{~d}$ \\
\hline P16 & $14.22 \mathrm{abc}$ & $2.68 \mathrm{cde}$ & NIV & $0.04 \mathrm{e}$ & $8.57 \mathrm{~b}$ & $0.08 \mathrm{f}$ & $<0.04 b$ & $8.70 \mathrm{~d}$ \\
\hline P17 & $13.62 \mathrm{bc}$ & 4.41 bcde & DON & 9.89 cde & $18.28 \mathrm{a}$ & $1.22 \mathrm{bc}$ & $0.75 \mathrm{a}$ & $29.93 \mathrm{~b}$ \\
\hline S19 & $20.41 \mathrm{ab}$ & $8.16 \mathrm{a}$ & DON, NIV & $1.19 \mathrm{e}$ & $4.21 \mathrm{bc}$ & $0.08 \mathrm{f}$ & $<0.04 b$ & $5.50 \mathrm{~d}$ \\
\hline S21 & $5.02 \mathrm{~d}$ & $2.02 \mathrm{de}$ & DON, NIV & $5.81 \mathrm{de}$ & $16.30 \mathrm{a}$ & $0.53 \mathrm{def}$ & $0.75 \mathrm{a}$ & $23.39 \mathrm{bc}$ \\
\hline $\mathrm{S} 22$ & $14.75 \mathrm{abc}$ & $5.19 \mathrm{abc}$ & DON, NIV & $0.34 \mathrm{e}$ & $5.51 \mathrm{bc}$ & ND & ND & $5.90 \mathrm{~d}$ \\
\hline $\mathrm{S} 23$ & $20.98 \mathrm{a}$ & $6.06 \mathrm{ab}$ & DON & $39.68 \mathrm{a}$ & $3.21 \mathrm{bc}$ & $0.99 \mathrm{bcd}$ & $0.10 \mathrm{~b}$ & $43.98 \mathrm{a}$ \\
\hline W09 & $18.95 \mathrm{ab}$ & 2.47 cde & DON, NIV & 9.44 cde & $3.64 \mathrm{bc}$ & 0.44 def & $<0.04 b$ & $13.53 \mathrm{~cd}$ \\
\hline W10 & $8.42 \mathrm{~cd}$ & $2.49 \mathrm{cde}$ & DON, NIV & $26.42 \mathrm{~b}$ & $4.84 \mathrm{bc}$ & $2.02 \mathrm{a}$ & $<0.04 \mathrm{~b}$ & $33.31 \mathrm{ab}$ \\
\hline W31 & $20.81 \mathrm{ab}$ & $7.33 \mathrm{ab}$ & DON, NIV & $27.24 \mathrm{~b}$ & $1.40 \mathrm{c}$ & $1.62 \mathrm{ab}$ & ND & $30.26 \mathrm{~b}$ \\
\hline W34 & $19.58 \mathrm{ab}$ & $4.91 \mathrm{bcd}$ & DON, NIV & $12.74 \mathrm{~cd}$ & $2.83 \mathrm{bc}$ & $0.09 \mathrm{f}$ & $0.26 \mathrm{ab}$ & $15.92 \mathrm{~cd}$ \\
\hline W36 & $14.30 \mathrm{abc}$ & 4.20 bcde & DON & $6.82 \mathrm{de}$ & $8.17 \mathrm{~b}$ & 0.10 ef & $0.19 \mathrm{~b}$ & $15.29 \mathrm{~cd}$ \\
\hline W37 & $21.10 \mathrm{a}$ & $5.29 \mathrm{abc}$ & DON, NIV & $2.83 \mathrm{de}$ & $2.57 \mathrm{bc}$ & ND & ND & $5.40 \mathrm{~d}$ \\
\hline W38 & $8.85 \mathrm{~cd}$ & $6.39 \mathrm{ab}$ & DON, NIV & $19.17 \mathrm{bc}$ & $5.38 \mathrm{bc}$ & 0.72 cde & ND & $25.27 \mathrm{bc}$ \\
\hline $\mathrm{LSD}^{y}$ & 7.27 & 3.13 & $\ldots$ & 9.95 & 6.04 & 0.63 & 0.51 & 11.80 \\
\hline Frequency $(\%)^{\mathrm{z}}$ & $\ldots$ & $\ldots$ & $\ldots$ & 100 & 100 & 86 & 71 & 100 \\
\hline
\end{tabular}

t Trichothecene amounts are expressed in dry weight of rotted potato tissue.

" FDR = Fusarium dry rot.

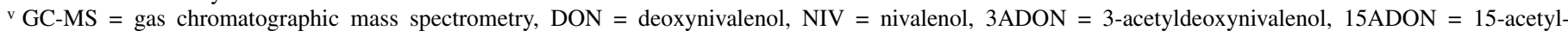
deoxynivalenol, < indicates that the trichothecene was detected under the limit of quantification, and ND indicates no detected trichothecene.

${ }^{w}$ Trichothecenes detected by thin-layer chromatography (TLC).

$\mathrm{x}$ Total trichothecenes.

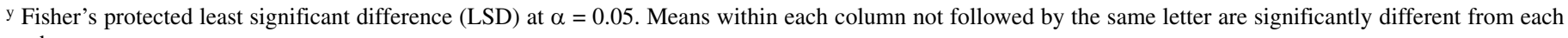
other.

${ }^{\mathrm{z}}$ Frequency of occurrence: percentage of each trichothecene within the studied isolates. 
adjacent asymptomatic tissue $3 \mathrm{~cm}$ away from the lesion margin. No significant differences were found between the adjacent asymptomatic tissue 2 and $3 \mathrm{~cm}$ away from the lesion, with 11 and $3 \%$ of recovery at 2 and $3 \mathrm{~cm}$ distal to the lesion margin, respectively. Similar results were observed after 5 weeks of incubation, with $68,22,6$, and $4 \%$ of recovery of $F$. graminearum from the rotted tissue and adjacent asymptomatic tissue 1,2, and $3 \mathrm{~cm}$ distal to the lesion margin, respectively. After 7 weeks of incubation, colonization and penetration of $F$. graminearum were $82,68,64$, and $53 \%$ in the rotted tissue and adjacent asymptomatic tissue 1,2 , and $3 \mathrm{~cm}$ distal to the lesion, respectively. Colonization of the rotted tissue after 7 weeks was not statistically different from the adjacent asymptomatic tissue $1 \mathrm{~cm}$ away from the lesion and, similarly, this section was not different from the adjacent asymptomatic tissue $2 \mathrm{~cm}$ away from the lesion margin, and the adjacent asymptomatic tissue $2 \mathrm{~cm}$ away from the lesion was not different from the adjacent asymptomatic tissue $3 \mathrm{~cm}$ distal to the lesion margin. A clear increase in the colonization of $F$. graminearum occurred in the rotted tissue, which was significantly different between 3 and 7 weeks of incubation. This increase was more pronounced in the adjacent asymptomatic tissue, which was statistically greater at 7 weeks of incubation than at both 3 and 5 weeks of incubation (Table 4).

The ANOVA of DON in the diffusion experiment showed significant differences among sections $(P<0.0001)$. It did not show significant differences across incubation times. However, significant differences were found among incubation times when the section $1 \mathrm{~cm}$ distal from the lesion margin was studied by itself $(P=0.0294)$. The concentration of DON from the rotted tissue was $11.72 \mu \mathrm{g} / \mathrm{ml}$ after 3 weeks of incubation, which was significantly different from the adjacent asymptomatic tissue 1, 2, and $3 \mathrm{~cm}$ away from the lesion margin (Table 4). DON was detected at $1 \mathrm{~cm}$ distal to the lesion margin at a concentration of $0.05 \mu \mathrm{g} / \mathrm{ml}$, which was not significantly different from the adjacent asymptomatic tissue 2 and $3 \mathrm{~cm}$ away from the lesion margin, where DON was detected under the limit of quantification. Similar results were observed after 5 and 7 weeks of incubation. DON was detected in a concentration of $13.79 \mu \mathrm{g} / \mathrm{ml}$ in the rotted tissue and $0.15 \mu \mathrm{g} / \mathrm{ml}$ in the adjacent asymptomatic tissue $1 \mathrm{~cm}$ distal to the lesion margin after 5 weeks of incubation. In the adjacent asymptomatic tissue 2 and $3 \mathrm{~cm}$ distal from the lesion, DON was detected under the limit of quantification after 5 weeks of incubation. DON was detected in concentrations of 19.11 and $0.54 \mu \mathrm{g} / \mathrm{ml}$ in the rotted tissue and adjacent asymp- tomatic tissue $1 \mathrm{~cm}$ distal to the lesion margin, respectively, after 7 weeks of incubation. In the adjacent asymptomatic tissue 2 and $3 \mathrm{~cm}$ away from the lesion, DON was detected under the limit of quantification after 7 weeks of incubation. The concentration of DON increased over time in the rotted tissue and in adjacent asymptomatic tissue at $1 \mathrm{~cm}$ distal to the lesion margin (Table 4). The concentration of DON in rotted tissue increased from $11.72 \mu \mathrm{g} / \mathrm{ml}$ at 3 weeks of incubation to $19.11 \mu \mathrm{g} / \mathrm{ml}$ at 7 weeks of incubation. The concentration of DON at $1 \mathrm{~cm}$ distal to the lesion margin increased from $0.05 \mu \mathrm{g} / \mathrm{ml}$ at 3 weeks of incubation to $0.54 \mu \mathrm{g} / \mathrm{ml}$ at 7 weeks of incubation, which was significantly different from 3 and 5 weeks of incubation. Also, NIV was also found only in the rotted tissue at concentrations of 2.79, 2.39, and $3.44 \mu \mathrm{g} / \mathrm{ml}$ after 3,5 , and 7 weeks of incubation (data not shown).

\section{DISCUSSION}

The trichothecenes DON, NIV, 3ADON, and 15ADON were detected predominantly in the rotted tissue of potato tubers rather than in the adjacent asymptomatic tissue. These results suggest that trichothecenes produced by $F$. graminearum in potato tubers generally do not diffuse far from the rotted tissue to the adjacent asymptomatic tissue when tubers are stored at commercial storage conditions of 10 to $12^{\circ} \mathrm{C}$. However, in a previous study, DON was detected $(0.54 \mu \mathrm{g} / \mathrm{ml})$ at $1 \mathrm{~cm}$ distal to a dry rot lesion after 7 weeks of incubation at a higher temperature of $20^{\circ} \mathrm{C}(10)$. In this same study, trichothecenes were detected in the asymptomatic tissue at concentrations $<1 \mu \mathrm{g} / \mathrm{ml}$ up to $3 \mathrm{~cm}$ away from the lesion margin when tubers had been inoculated with $F$. graminearum and stored at $20^{\circ} \mathrm{C}$. Lafont et al. (22) also found low amounts of some trichothecenes (DAS, DON, and T-2 toxin) in the adjacent asymptomatic tissue when potato tubers inoculated or naturally infected with $F$. sambucinum were incubated at 12 to $16^{\circ} \mathrm{C}$. It seems that cooler temperatures may retard the advance of trichothecenes to the adjacent asymptomatic tissue. Similarly, Xu et al. (37) showed that trichothecene production is enhanced by warmer temperatures during initial infection of wheat heads, and there is a strong positive correlation between DON concentration and fungal biomass in wheat heads $(6,37)$. In the present study, $F$. graminearum penetrated the asymptomatic tissue of potato tubers more rapidly than DON diffused into them. Our results suggest that DON accumulation in the adjacent asymptomatic tissue occurred after $F$. graminearum has penetrated and colonized the adjacent asymptomatic tissue. Laidou et al. (23) showed that the

TABLE 4. Recovery of Fusarium graminearum and accumulation of deoxynivalenol (DON) in potato tubers affected by FDR grouped by incubation time ${ }^{\mathrm{x}}$

\begin{tabular}{|c|c|c|}
\hline Incubation time and sections & Recovery of $F$. graminearum (\%) & Accumulation of DON $(\mu \mathrm{g} / \mathrm{ml})^{\mathrm{y}}$ \\
\hline \multicolumn{3}{|l|}{3 weeks } \\
\hline Rotted tissue & $59.67 \mathrm{a}$ & $11.72 \mathrm{a}$ \\
\hline Asymptomatic tissue $1 \mathrm{~cm}$ distal & $25.00 \mathrm{~b}$ & $0.05 \mathrm{~b}$ \\
\hline Asymptomatic tissue $3 \mathrm{~cm}$ distal & $2.83 \mathrm{c}$ & $<0.04 \mathrm{~b}$ \\
\hline $\mathrm{LSD}^{\mathrm{z}}$ & 18.51 & 3.45 \\
\hline \multicolumn{3}{|l|}{5 weeks } \\
\hline Rotted tissue & $68.08 \mathrm{a}$ & $13.79 \mathrm{a}$ \\
\hline Asymptomatic tissue $3 \mathrm{~cm}$ distal & $4.17 \mathrm{c}$ & $<0.04 \mathrm{~b}$ \\
\hline $\mathrm{LSD}^{\mathrm{z}}$ & 12.72 & 4.25 \\
\hline \multicolumn{3}{|l|}{7 weeks } \\
\hline Rotted tissue & $81.75 \mathrm{a}$ & $19.11 \mathrm{a}$ \\
\hline Asymptomatic tissue $1 \mathrm{~cm}$ distal & $68.00 \mathrm{ab}$ & $0.54 \mathrm{~b}$ \\
\hline Asymptomatic tissue $2 \mathrm{~cm}$ distal & $64.00 \mathrm{bc}$ & $<0.04 \mathrm{~b}$ \\
\hline Asymptomatic tissue $3 \mathrm{~cm}$ distal & $52.75 \mathrm{c}$ & $<0.04 \mathrm{~b}$ \\
\hline
\end{tabular}

$\overline{\mathrm{x}}$ Recovery was calculated as percentage of isolations positive for $F$. graminearum growth over the total number of isolations. Data represent means for two trials. Means within each column not followed by the same letter are significantly different from each other.

${ }^{\mathrm{y}}$ DON concentration expressed in dry weight.

${ }^{\mathrm{z}}$ Fisher's protected least significant difference (LSD) at $\alpha=0.05$. 
accumulation of patulin, another mycotoxin, in the asymptomatic tissue of pear fruit occurred after Penicillium expansum, Aspergillus flavus, or Alternaria alternata had penetrated the adjacent asymptomatic tissue. Laidou et al. (23) suggested that this may be a mechanism of breaking the host defenses. In potato tubers, the infecting hyphae may be intercellular in the margin of the dry rot lesion and in the asymptomatic tissue where potato shows little reaction to $F$. sambucinum (33) and possibly also to $F$. graminearum. In this regard, it is important to mention that fungal growth may be retarded at low temperatures which could prevent the accumulation of DON in the asymptomatic tissue and also decrease trichothecene diffusion from the rotted tissue by decreasing their solubility of trichothecenes.

Potato tubers can defend themselves from pathogen attacks, for example, using phytoalexins which are elicited by arachidonic acid. These phytoalexins, as well as trichothecenes, are members of the chemical family of sesquiterpenes and can be metabolized by the pathogen $(3,12,15)$. Thus, one might hypothesize that Fusarium trichothecenes may be an alternate substrate for a sesquiterpene enzyme involved in the biosynthetic pathway of phytoalexins in potato tubers affected with FDR. The high water content of potato tubers may facilitate such enzymatic reactions. Because $F$. graminearum produces neither an appressorium nor a haustorium but, instead, attacks the host by cell-wall-degrading enzymes such as cellulases, pectinases, and xylanases $(21,35)$, this could explain the release of cytoplasmic enzymes by the host cells in contact with $F$. graminearum trichothecenes. However, further studies need to be done in this area in order to support this hypothesis. The interaction between tissue and toxin indicates that some trichothecenes are produced in larger quantities than others: more toxin accumulation in the rotted tissue rather than the adjacent asymptomatic tissue may be due to the differential solubility of these trichothecenes.

DON was the most predominant mycotoxin accumulated in rotted potato tissue. However, $3 \mathrm{ADON}$ and $15 \mathrm{ADON}$ were also found in rotted tissue. The trichothecene $3 \mathrm{ADON}$ was found in higher amounts and in higher frequency than $15 \mathrm{ADON}$. This is consistent with the results of Gale et al. (19), who found that most of the F. graminearum isolates collected from wheat fields from North Dakota and Minnesota are 3ADON chemotype rather than $15 \mathrm{ADON}$, the chemotype most common in the rest of the North American population.

DON and NIV accumulated together in the rotted tissue of potato tubers infected by all the studied isolates. $F$. graminearum isolates are often classified as either DON or NIV genotype or chemotype $(7,20,34)$. This classification is important in order to assess the toxicological potential of crops infected by F. graminearum. In this regard, NIV has been found to be more acutely toxic than DON in animal systems but less toxic in Arabidopsis thaliana and wheat $(11,14)$. DON is frequently and predominantly found in FHB-infected grains in the United States $(11,26)$. Therefore, the accumulation of DON and NIV together from single-spore isolates of $F$. graminearum inoculated into potato tubers is rather unusual. All 12 DON genotype isolates accumulated DON and NIV in the rotted tissue of potato tubers as detected by TLC and GC-MS analyses. The two NIV genotype isolates also produced both DON and NIV, although DON was detected in extremely low amounts. Sugiura et al. (32) determined that NIV-producing isolates could produce very small amounts of DON but DON-producing isolates did not produce NIV. Molecular analysis of DON-producing isolates that do not produce NIV indicated that this is due to the presence of a nonfunctional Tril3 gene (7). The Tril3 gene encodes for the enzyme calonectrin 4-oxygenase which is responsible for the oxygenation of C-4 of trichothecenes, a major difference between NIV and DON genotype isolates. Several plant pathogens use toxins as virulence factors during disease establishment and development in host plants, and plants have the ability to defend themselves from pathogens and their toxins (10). Thus, the accumulation of NIV in the rotted tissue of potato tubers could be partially explained by enzymatic conversion of DON into NIV in the rotted tissue; however, no specific DON-to-NIV conversion enzymes have been reported in potato tubers. The metabolism of DAS by potato tuber enzymes has been previously suggested by Desjardins et al. (13). DAS is deacetylated to 15MAS and then to scirpenetriol by potato enzymes.

Two preliminary experiments were conducted using raw and cooked (microwaved for $1 \mathrm{~min}$ ) potato tuber slices inoculated with $F$. graminearum to determine the presence of enzymes in potato that might interact with $F$. graminearum trichothecenes. When the potato slices were spiked with $25 \mu \mathrm{l}$ of DON at 10 $\mathrm{mg} / \mathrm{ml}, 83 \%$ of the toxin was recovered from cooked potato slices but none was recovered from the raw slices $4 \mathrm{~h}$ after DON spiking. In the second experiment, the slices were inoculated with two isolates of $F$. graminearum, P15 (NIV-genotype), or S23 (DON-genotype) and incubated for 1 week. NIV was detected at high levels in raw slices inoculated with P15, and low amounts of DON were found. However, infection of raw slices with isolate S23 produced very high amounts of DON and NIV in lower amounts but $>1 \mu \mathrm{g} / \mathrm{ml}$. When the same isolates were inoculated in cooked slices, isolate P15 showed again high amounts of NIV and low amounts of DON. However, isolate S23 accumulated only DON. These two preliminary experiments support our hypothesis that potato enzymes might be implicated in the accumulation of NIV in potato tubers by interaction of these enzymes with trichothecenes intermediates produced by $F$. graminearum (9).

The present study concludes that $F$. graminearum is able to produce and accumulate type $B$ trichothecenes in the rotted tissue of potato tubers affected by dry rot caused by $F$. graminearum. It appears that the accumulated trichothecenes do not significantly diffuse into the surrounding adjacent asymptomatic tissue when potato tubers are stored at 10 to $12^{\circ} \mathrm{C}$ for up to 7 weeks but there is a slight trend to increase in the adjacent asymptomatic tissue. Therefore, it is recommended to store potato tubers at a low temperature $\left(<10^{\circ} \mathrm{C}\right)$ and to remove rotted tissue with at least 1 to $2 \mathrm{~cm}$ of asymptomatic tissue prior to consumption or manufacture in order to minimize trichothecene contamination of fresh and manufactured potato foods and feeds. However, further studies are necessary to fully understand the diffusion of these mycotoxins in potato tubers at longer incubation periods and in different potato cultivars such as Umatilla Russet, a cultivar highly susceptible to dry rot.

\section{LITERATURE CITED}

1. Acuña, I., Mancilla, S., Sagredo, B., Gutiérrez, M., Vargas, M., and Delgado, J. 2004. Identificación taxonómica de las especies de Fusarium causantes de pudrición seca en tubérculos de papa en el sur de Chile. In: (Abstr.) 55th Congreso Agronómico de Chile.

2. Ali, S., Rivera, V. V., and Secor, G. A. 2005. First report of Fusarium graminearum causing dry rot of potato in North Dakota. Plant Dis. 89:105.

3. Bostock, R. M., Kuc, J. A., and Laine, R. A. 1981. Eicosapentaenoic and arachidonic acid from Phytophthora infestans elicit fungitoxic sesquiterpenes in the potato. Science 212:67-69.

4. Bullerman, L. B., and Bianchini, A. 2007. Stability of mycotoxins during food processing. Int. J. Food Microbiol. 119:140-146.

5. Burlakoti, R. R., Ali, S., Secor, G. A., Neate, S. M., McMullen, M. P., and Adhikari, T. B. 2008. Genetic relationship among populations of Gibberella zeae from barley, wheat, potato, and sugar beet in the upper Midwest of the United States. Phytopathology 98:969-976.

6. Burlakoti, R. R., Estrada, R., Jr., Rivera, V. V., Boddeda, A., Secor, G. A., and Adhikari, T. B. 2007. Real-time PCR quantification and mycotoxin production of Fusarium graminearum in wheat inoculated with isolated collected from potato, sugar beet, and wheat. Phytopathology 97:835-841.

7. Chandler, E. A., Simpson, D. R., Thomsett, M. A., and Nicholson, P. 2003. Development of PCR assays to Tri7 and Tril3 trichothecene biosynthesic genes, and characterization of chemotypes of Fusarium graminearum, Fusarium culmorum and Fusarium cerealis. Physiol. Mol. Plant Pathol. 62:355-367. 
8. Corsini, D. L., and Pavek, J. J. 1986. Fusarium dry rot resistant potato germplasm. Am. Potato J. 63:629-638.

9. Delgado, J. A., Schwarz, P. B., Gillespie, J., Rivera, V. V., and Secor, G. A. 2009. Accumulation of Nivalenol in Potato Tubers Infected with DONProducing Strains of Fusarium graminearum. Sociedad Chilena de Fitopatologia, Santiago, Chile.

10. Delgado, J. A., Schwarz, P. B., Gudmestad, N. C., Gillespie, J., Rivera, V. V., and Secor, G. A. 2009. Production and Distribution of Mycotoxins in Potato Tubers Affected with Dry Rot Caused by Fusarium graminearum. Sociedad Chilena Fitopatologia, Santiago, Chile.

11. Desjardins, A. E. 2006. Pages 13-64 and 166-168 in: Fusarium Mycotoxins: Chemistry, Genetics and Biology, 1st ed. American Phytopathological Society, St. Paul, MN.

12. Desjardins, A. E., Gardner, H. W., and Weltring, K-M. 1992. Detoxification of sesquiterpene phytoalexins by Gibberella pulicaris (Fusarium sambucinum) and its importance for virulence on potato tubers. J. Ind. Microbiol. 9:201-211.

13. Desjardins, A. E., Hohn, T. H., and McCormick, S. P. 1992. Effect of gene disruption of trichodiene synthase on the virulence of Gibberella pulicaris. Mol. Plant-Microbe Interact. 5:214-222.

14. Desjardins, A. E., McCormick, S. P., and Apell, M. 2007. Structureactivity relationships of trichothecene toxins in an Arabidopsis thaliana leaf assay. J. Agric. Food Chem. 55:6487-6492.

15. Desjardins, A. E., McCormick, S. P., and Corsini, D. L. 1995. Diversity of sesquiterpenes in 46 potato cultivars and breeding selections. J. Agric. Food. Chem. 43:2267-2272.

16. Desjardins A. E., and Plattner, R. D. 1989. Trichothecene toxin production by strains of Gibberella pulicaris (Fusarium sambucinum) in liquid culture and in potato tubers. J. Agric. Food Chem. 37:388-392.

17. El-Banna, A. A., Scout, P. M., Lau, P-Y., Sakuma, T., Platt, H. W., and Campbell, V. 1984. Formation of trichothecenes by Fusarium solani var. coeruleum and Fusarium sambucinum in potatoes. Appl. Environ. Microbiol. 47:1169-1171.

18. Estrada, R., Gudmestad, N. C., Rivera, V. V., and Secor, G. A. 2010. Fusarium graminearum as a dry rot pathogen of potato: Prevalence, aggressiveness and factors affecting etiology. Plant Pathol. (In press.)

19. Gale, L. R., Ward, T., Balmas, V., and Kistler, H. C. 2003. Population subdivision in Fusarium graminearum lineage 7 in the U.S. is correlated with toxin chemotype. Fungal Genet. Newsl. 50 (Suppl.):454.

20. Ichinoe, M., Kurata, H., Sugiura, Y., and Ueno, Y. 1983. Chemotaxonomy of Gibberella zeae with special reference to production of trichothecenes and zearalenone. Appl. Environ. Microbiol. 46:1364-1369.

21. Jenczmionka, N. J., and Schafer, W. 2005. The Gpmk1 MAP kinase of Fusarium graminearum regulates the induction of specific secreted enzymes. Curr. Genet. 47:29-36.

22. Lafont, P., Girard, T., Payen, J., Sarfati, J., and Gaillardin, M. 1983. Contamination de pommes de terre de consommation par des fusariotrichothecenes. Microbiol. Alim. Nutr. 1:147-152.
23. Laidou, I. A., Thanassoulopoulos, C. C., and Liakopoulou-Kyriakides, M. 2001. Diffusion of patulin in the flesh of pears inoculated with four postharvest pathogens. J. Phytopathol. 149:457-461.

24. Lauren D. R., and Smith, W. A.. 2001. Stability of the Fusarium mycotoxins nivalenol, deoxynivalenol and zearalenone in ground maize under typical cooking environments. Food Addit. Contam. 18:1011-1016.

25. Logrieco, A., Mulè, G., Moretti, A., and Botallico, A. 2002. Toxigenic Fusarium species and mycotoxins associated with maize ear rot in Europe. Eur. J. Plant Pathol. 108:597-609.

26. McMullen, M., Jones, R., and Gallenberg, D. 1997. Scab of wheat and barley: A re-emerging disease of devastating impact. Plant Dis. 81:13401348 .

27. National Agriculture Statistics Service (NASS). 2008 Page 21 in: Crop Production December 2008. NASS, U.S. Dep. Agric.

28. Nicholson, P., Rezanoor, H. N., Simpson, D. R., and Joyce, D. 1997. Differentiation and quantification of the cereal eyespot fungi Tapesia yallundae and Tapesia acuformis using a PCR assay. Plant Pathol. 46:842-856.

29. Peters, J. C., Lees, A. K., Cullen, D. W., Sullivan, L., Stroud, G. P., and Cunnington, A. C. 2008. Characterization of Fusarium spp. responsible for causing dry rot potato in Great Britain. Plant Pathol. 57:262-271.

30. Proctor, R. H., Hohn, T. M., and McCormick, S. P. 1995. Reduced virulence of Gibberella zeae caused by disruption of trichothecene toxin biosynthetic gene. Mol. Plant-Microbe Interact. 8:593-601.

31. Samson, R. A, Hoekstra, E. S., and Frisvad J. C. 2004. Introduction to food- and airborne fungi. Pages 290-291 in: Methods for the Detection, Isolation and Characterization of Food-Borne Fungi, 7th ed. CBS, Wageningen, The Netherlands.

32. Schwarz, P. B., Casper, H. H., and Beatle, S. 1995. Fate and development of naturally occurring Fusarium mycotoxins during malting and brewing. J. Am. Soc. Brew. Chem. 53:121-127.

33. Secor, G. A., and Salas, B. 2001. Fusarium dry rot and Fusarium wilt. In: Compendium of Potato Diseases, 2nd ed. W. R. Stevenson, R. Loria, G. D. Franc, and D. P. Weingartner, eds. American Phytopathological Society Press, St. Paul, MN

34. Sugiura, Y., Watanabe, Y., Tanaka, T., Yamamoto, S., and Ueno, Y. 1990. Occurrence of Gibberella zeae that produce both nivalenol and deoxynivalenol. Appl. Environ. Microbiol. 56:3047-3051.

35. Wanjiru, W. M., Kang, Z. S., and Buchenauer, H. 2002. Importance of cell wall degrading enzymes produced by Fusarium graminearum during infection of wheat heads. Eur. J. Plant Pathol. 108:803-810.

36. Widestrand, J., and Petterson, H. 2001. Effect of time, temperature and solvent on the stability of T-2 toxin, HT-2 toxin, deoxynivalenol and nivalenol calibrants. Food Addit. Contam. 18:987-992.

37. Xu, X.-M., Monger, W., Ritieni, A., and Nicholson, P. 2007. Effect of temperature and duration of wetness during initial infection periods on disease development, fungal biomass and mycotoxin concentrations on wheat inoculated with single, or combinations of, Fusarium species. Plant Pathol. 56:943-956. 